\title{
Canada's Environmental Farm Plan: Evaluating Implementation, Use of Services, and the Influence of Social Factors
}

\author{
Paul Smith ${ }^{1,8}$, Carrie Bibik ${ }^{2}$, Jon Lazarus ${ }^{3}$, David Armitage ${ }^{3}$, Cindy Bradley-Macmillan ${ }^{1}$, Maxine Kingston ${ }^{4}$, \\ Andrew Graham ${ }^{5}$, Ryan Plummer ${ }^{6} \&$ Robert Summers ${ }^{7}$ \\ ${ }^{1}$ Ontario Ministry of Agriculture, Food and Rural Affairs, 1 Stone Road West, Guelph, ON, N1H 1R1, Canada \\ ${ }^{2}$ Alberta Ministry of Children's Services, 10th fl Sterling Place, 9940-106 Street, Edmonton, AB, T5K 2N2, \\ Canada \\ ${ }^{3}$ Ontario Federation of Agriculture, 100 Stone Road West, Suite 206, Guelph, ON, N1G 5L3, Canada \\ ${ }^{4}$ Agriculture and Agri-Food Canada, 174 Stone Road West, Guelph, ON, N1G 4S9, Canada \\ ${ }^{5}$ Ontario Soil and Crop Improvement Association, 1 Stone Road West, Guelph, ON, N1G 4Y2, Canada \\ ${ }^{6}$ Brock University, Environmental Sustainability Research Centre, 1812 Sir Isaac Brock Way, St. Catharines, \\ Ontario, L2S 3A1, Canada \\ ${ }^{7}$ University of Alberta, School of Urban and Regional Planning, 3-90 Tory Building, 11211 Saskatchewan Drive \\ NW, Edmonton AB, T6G 2H4, Canada \\ ${ }^{8} 33$ Division Street, Guelph, ON, Canada \\ Correspondence: Paul Smith, 33 Division Street, Guelph, ON, N1H 1R1, Canada. E-mail: paul@paulsmith.work
}

Received: June 21, 2020 Accepted: July 21, 2020 Online Published: August 8, 2020

doi:10.5539/sar.v9n4p1 URL: https://doi.org/10.5539/sar.v9n4p1

\begin{abstract}
Canada's Environmental Farm Plan (EFP) is a voluntary, self-administered education and risk assessment tool that assists farmers in developing customized action plans to address environmental risks on their farms. During 2010-11 a study was undertaken in Ontario to evaluate the level of implementation of the EFP, the use of related services and resources, and social factors influencing implementation and services used. A confidential survey of 189 Ontario farmers with EFPs revealed high levels of implementation and significant investments of time and money to reduce environmental risks and improve environmental conditions. Farmers completed or were implementing $67.5 \%$ (median) of their action plans, up from 55\% reported in a survey in 1999. Farmers invested an average of $\mathrm{C} \$ 69,600$ per farm in agri-environmental activities (of which $73 \%$ was drawn from their own funds) and spent 130 hours of their time per farm. Percent implemented, time and cost are all much higher compared to the survey in 1999. Farmers used many existing services in preparing and implementing their EFPs. In 2010, social factors significantly influenced motivation, preferences and service needs including education, age and main commodity produced. Also in $2010,95 \%$ percent of farmers reported perceived environmental improvements on their farm operations. The results emphasize the importance of combining risk assessment, education and financial incentives as well as offering a range of program services to appeal to the varied needs of different farmers.
\end{abstract}

Keywords: agriculture, agri-environment, risk assessment, evaluation, sustainability, social factors

\section{Introduction}

Canada's Environmental Farm Plan (EFP) Program is a long-term partnership between farm organizations and the Canadian federal and Ontario and other provincial governments based on a voluntary, self-administered educational and risk assessment approach (Ontario Farm Environment Coalition, Agriculture and Agri-Food Canada \& Ontario Ministry of Agriculture Food and Rural Affairs, 2013; Summers, Plummer, \& FitzGibbon, 2008; Plummer, Speirs, A., Summers, R. \& FitzGibbon, 2007; Robinson, 2006a, b). The EFP began as a proposal from farm organizations in 1992 (Ontario Farm Ontario Farm Environment Coalition, 1992) and was developed through a consensus-based process supported by the Canadian and Ontario governments (Smith, 2015; Robinson, 2006a, b). EFP has evolved over time (Morrison and FitzGibbon, 2014), spreading across Canada and continues today under the 2018-2023 Canadian Agricultural Partnership framework (Agriculture and Agri-Food Canada 
and Ministry of Agriculture Food and Rural Affairs, 2018). The EFP Program is a primary vehicle for agri-environmental stewardship in Canada, enjoys high levels of participation and acceptance (Smith, 2015) and wide adoption across Canada (Statistics Canada, 2013, 2019; Clearwater, Martin, \& Hoppe, 2016; Agriculture and Agri-Food Canada, 2009).

Like all government policy tools, the EFP must show effectiveness and always improve results. Agri-environmental policy across the nations of the Organization for Economic Cooperation and Development (OECD) and elsewhere struggles with evaluation and performance measurement (Ansell, Gibson, \& Salt, 2016; OECD, 2010, 2013; Manderson, Mackay, \& Palmer, 2007). Tracking increasing farmer participation in the EFP was for a long time a measure of effectiveness and performance (Smith, 2015, AAFC, 2009, Robinson, 2006a, b) Participation in EFP was 38\% of farms in Ontario and 35\% across Canada in 2011, now 46\% and 40\% respectively in 2016 based on sample surveys (Statistics Canada, 2019, 2013). A non-survey estimate of participation in Ontario is as high as 70\% of farms (Morrison and Fitzgibbon, 2014). As the EFP program has matured, better measures of effectiveness are needed.

The goal of the EFP is reducing the agri-environmental risks on farms across Canada through change of practices and private and public investment in environmental improvements. This leads to several questions about the EFP. To what degree are the plans implemented, and do they improve environmental quality (Boxall, 2018; Robinson, 2006a, b)? How can the level of implementation of EFPs be estimated for performance measurement, so important for public policy (Boxall, 2018, OECD, 2013, Manderson et al., 2007)? Statistics Canada (2013, 2019) surveyed farmers with a simple question of whether their EFPs are fully, partially or not implemented in 2001, 2006, 2011 and 2016, but not quantifying the level of implementation. A detailed survey and analysis were undertaken in Ontario in 1999 to quantify levels of implementation of EFPs (Summers et al., 2008; Plummer et al., 2007). The study presented here quantifies levels of implementation in 2010, the costs and time commitments required, and probes the social factors influencing preparation and implementation of EFPs.

This research was undertaken to study the effectiveness of the EFP program and identify ways to improve the program by:

1. Assessing the level of implementation of EFP action plans and the time and cost needed for implementation;

2. Gauging the use of current and possible additional services and resources to assist farmers to complete and implement their EFPs; and

3. Evaluating the effect of social, economic and demographic factors on EFP implementation, motivation for participation and use of services and resources for preparation and implementation.

The research builds on a previous survey completed in 1999 and replicates some questions for direct comparison (Plummer et al., 2007; Summers et al., 2008).

\subsection{Background on Environmental Farm Plan}

The EFP is similar to many agri-environmental planning tools in other jurisdictions (Robinson, 2006a, b), although the collaborative government-farm organization partnership model has unique aspects (Morrison and FitzGibbon, 2014). EFP is also a special case of a broad range of risk assessment tools used in agriculture (Leppala, Rautiainen, \& Kauranen, 2015). In the last decade, agri-environmental assessment tools are increasingly becoming part of farm and food sustainability assessment systems (Inwood et al., 2018; de Olde, Oudshoorn, F., Sørensen, C., Bokkers, \& de Boer, 2016), an application being explored for the EFP (Wilton and Smith, 2017).

Considerable research has documented many aspects of the development and implementation of the EFP program over the years. Early research focused on the social acceptance of the program and farmer concerns about enforcement and confidentiality (Smithers and Furman, 2003; Yiridoe, 2000). As the EFP became popular and successful, research focused on effectiveness and accessibility (Morrison and FitzGibbon, 2014; Yiridoe, Atari, D., Gordon, \& Smale, 2010; Robinson, 2006a, b; Smithers and Furman, 2003).

Many factors influence farmer participation in EFP, as in other agri-environmental programs (Baumgart-Getz, Prokopy, \& Floress, 2012; Yiridoe et al., 2010; Lambda, Filson, \& Adekunle, 2009; Prokopy, Floress, Klotthor-Weinkauf, \& Baumgart-Getz, 2008; Panell et al., 2006). Behavioural, economic and demographic factors affect the needs and motivations of producers in terms of participation, knowledge and financing (Carlisle, 2016; Reimer, Klotthor Weinkauf, \& Prokopy, 2014; Sattler and Nagel, 2010). Knowledge of the influence of social factors and diverse needs can be used to design policy and programs to enhance participation (Dessart, Barreiro-Hurlé, \& van Bavel, 2019; Reimer et al., 2014).

The early, mid, late and non-adopter terminology (Rogers, 2010) is often used to characterize farmers that do or 
do not participate in agri-environmental programs such as the EFP. Current EFP participants likely fall mostly in the early to mid-adopter categories, although mature programs like EFP likely draw in some later adopters. As Carlisle (2016) shows, understanding of barriers to non-adopters' participation is poor, perhaps inevitably so due to the lack of interest. Nevertheless, increasing farmer participation in EFP in Ontario beyond the $38 \%$ in Ontario in 2011 (46\% in 2016) is an important goal. Reaching new audiences requires understanding their concerns and needs.

The growing heterogeneity among farmers (Weersink, 2018) suggests the need to understand what customized approaches might improve adoption of agri-environmental practices (Schaible, Mishra, Lambert, \& Panterov, 2015). Growth in behavioural science-based approaches to influencing decision making also suggests the potential of non-traditional approaches (Dessart et al., 2019; Reimer et al., 2014). Learning styles, values, peer networks, social norms, risk perception, family relationships, farm advisory network characteristics and extension outreach techniques are all important variables affecting the appeal of agri-environmental programs to farmers (Roussy, Ridier, \& Chaib, 2017; Carlisle, 2016; Wauters and Mathijs, 2014; Franz, Piercy, Donaldson, Richard, \& Westbrook, 2010; Prokopy et al., 2008; Ingram and Morris, 2007). Increasingly, public policy is using different tools and approaches to target influence for different groups of farmers based on their differences (e.g. Barnes, Willock, Toma, \& Hall, 2011).

\subsection{The Environmental Farm Planning Process: Prepare, Review, Implement}

The EFP is an educational process and risk assessment tool that helps farmers understand and assess the environmental risks on their own farms and develop an action plan to address those risks. Figure 1 illustrates the process followed to complete an EFP. A farmer attends a workshop and is led through the initial process of identifying environmental features on their farm and then through at least one of the 23 worksheets on different topics in the EFP workbook. The farmer then completes the relevant worksheets in the workbook that apply to their farm, given the farm's soils, water resources, natural features and production systems.

The farm review requires the farmer to rate the risk associated with practices and features on an ordinal scale of 1 to 4 , with 1 having the highest potential to negatively affect the environment and 4 having the lowest potential to negatively affect the environment. The workbook contains 319 possible risk ratings, depending on the commodities produced, the practices followed and environmental features on the farm.

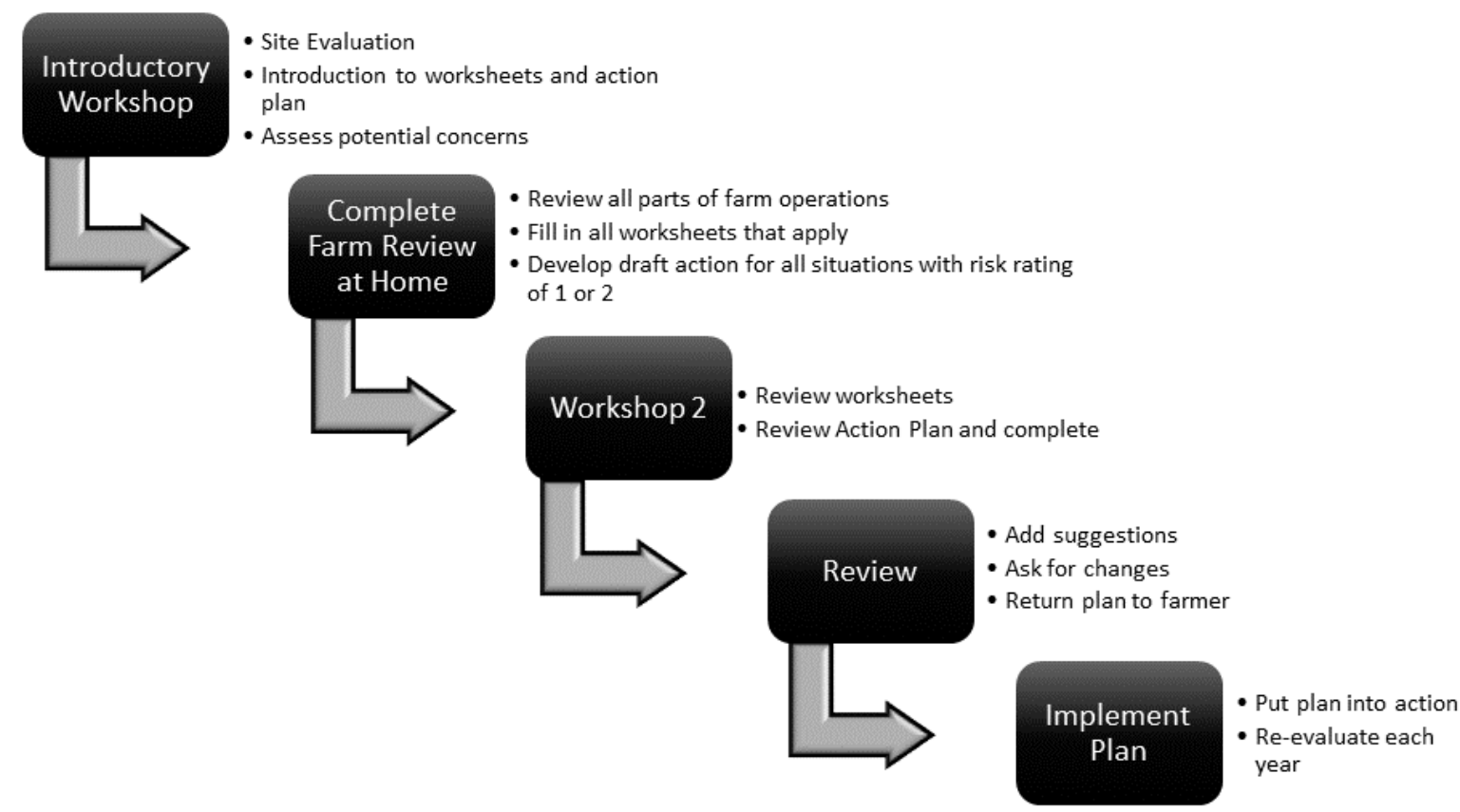

Figure 1. Environmental Farm Planning process

At the second workshop, the farmer reviews the risk ratings and completes an action plan that will improve all the lower risk ratings of 1 or 2 to higher ones, 3 or 4 . Where the rating can't be improved, compensating factors are identified to manage potential risk. This EFP action plan can then be submitted for review by a 
knowledgeable agricultural staff person, who provides comments and suggestions. After the EFP action plan is verified by the reviewer, the farmer is ready to implement the action plan.

\section{Methods}

\subsection{Survey}

The research conducted a two-stage survey of 189 EFP participants to collect data on producers' experiences with the EFP Program, their progress implementing their action plans, associated time and costs required, their perceptions of potential services, and socio-economic data that might influence survey results. The survey comprised two components: a self-completed questionnaire and an in-person interview. Research funding was provided through the federal-provincial Growing Forward agricultural policy framework.

The survey was completed with 189 Ontario producers who had a 3rd edition, reviewed EFP. These 189 participants were drawn from approximately 12,400 farmers that had a reviewed, 3rd edition by 2010 . The sample of producers interviewed was selected to be representative of Ontario producers based on major farm commodity type (e.g. field crops, livestock, horticulture) and representative of the farming regions of Ontario. The commodity targets were designed to reflect the distribution of farm commodity types across Ontario and based on the 2006 Census of Agriculture. The farmers participating reflect the regional diversity across Ontario, southeast, southwest, and northern regions (17 counties - southwest: Chatham-Kent, Wellington, Lambton, Huron, Oxford; southeast: Durham, Kawartha Lakes, Carleton, Dundas, Grenville, Prescott, Russell, and Prince Edward County; northern: Sudbury, Cochrane, Nippising, Parry Sound, Timiskaming). To protect the confidentiality of EFP participants, farm organization staff (Ontario Soil and Crop Improvement Association) conducted the in-person interviews and data entry for the survey. Staff people were trained in the survey methods to introduce them to the questionnaires, participant recruiting, interviewing and data entry processes.

The development of the survey questions was informed by the questionnaire used for the 1999 survey (Plummer et al., 2007; Summers et al., 2008), a literature review, and key informant interviews. The key informant interview is a qualitative research method often used to gain knowledge about a topic before undertaking quantitative surveys (Faifua, 2014). Eight interviews with Ontario Soil and Crop Improvement Association staff and EFP technical advisors, who have regular contact with participating farmers, were conducted to gain insight into concerns of farmers participating in the EFP Program. The draft questionnaires and associated data entry forms were pretested with four EFP program staff, all of whom are also farmers that have a verified EFP for their farms. These methods were designed to be comparable to those used in the 1999 survey.

\subsection{Variables}

The final questionnaire had 62 questions and included topics in categories including general attitudes, awareness and perceptions of the EFP program, history and extent of involvement in the EFP program, implementation of environmental projects including cost, resources, socio-economic and demographic characteristics of the farm including agricultural commodities, extent of land owned and rented, business arrangements, age, education, farm income, and off-farm income. These variables have commonly been identified in the literature as important influences in adoption of agri-environmental practices (Schaible et al., 2015; Burton, 2014; Prokopy et al., 2008). The entire questionnaire can be found in the consultant's unpublished project report (Prairie Research Associates, 2011). The socio-economic and demographic variables are used to test for their impact on variables of interest such as level of implementation, use of existing services and preferences for possible new services. It is hoped that another future survey can be conducted to compare with 1999 and 2010.

The EFP includes up to 319 risk assessment ratings to cover most potential environment risks for Ontario farms. Each farm completes the ratings pertinent to their operation, production system and landscape features. The EFP action plan is composed of a series of activities to address all the risk ratings of 1 or 2 . These activities include specific actions or projects to address the risk, compensating factors that help manage the risk or monitoring activities that identify ways to monitor the risk factor. Each activity in the action plan may also address multiple risk ratings. The percentage of these activities that are completed or started was calculated for each farm. The cost and time spent in implementing these activities was also recorded and summed for each farm.

Comparisons presented in the results section are between survey results in 2010 with those from the 1999 survey. 179 EFP participants were surveyed in 1999, using similar survey methods which are outlined in more detail elsewhere (Summers et al., 2008; Plummer et al., 2007). Variables are compared where the methodology and wording of questions is consistent. A series of questions in the 1999 were repeated in the 2010 survey to allow for these comparisons, such as activities completed or not, cost of implementation, perceptions of improvements, and barriers to implementation. 


\subsection{Statistical Analysis}

A variety of statistical analyses was used for different purposes. Regression and analysis of variance (parametric and non-parametric tests) were used for analyzing continuous variables, and cross tabulation with chi-squared tests was used for categorical variables. Statistical tests were carried out using Statistical Package for the Social Sciences software, MegaStat Excel add-in (Oris, 2015) and native Microsoft Excel functions. Interpreting the results of the surveys and comparisons between the 1999 and 2010 samples must be done with caution.

\section{Results}

EFP action plans vary dramatically among farms depending on the farm's size, revenues, commodities produced and many other factors. Farmers who participated in the 2010 survey listed an average of 83 individual activities in their action plans, but the number of activities per action plan ranged from 8 to 380. Action plans were also more complex in 2010 as compared with 1999, the average in 2010 of 83 activities in their action plans, compared with 23 per producer in 1999. Similarly, on average, farmers identified a potential concern for 35 risk assessment questions (out of a possible 319), which is up from 23 questions in 1999.

\subsection{Level of Implementation of Action Plans}

Participating farms had completed or were in the process of implementing $67.5 \%$ of their EFP action plans in 2010 (Figure 2). This is higher than the 55.0\% in 1999 and the difference is statistically significant (Mann Whitney Test, $\mathrm{P}<0.0001$ ). Cost sharing programs were much more readily available in 2010 than in 1999, the EFP program has gained wide acceptance and social context had changed over time (Smith 2015; Morrison and Fitzgibbon 2014).

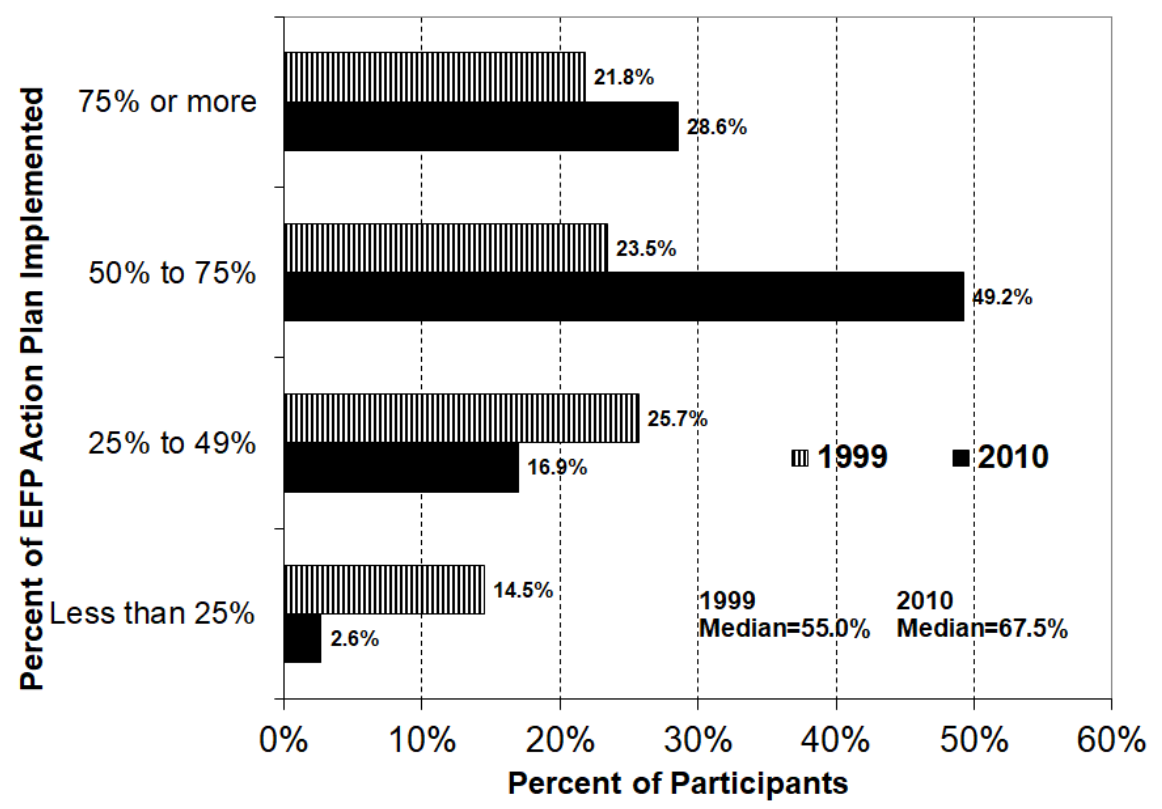

Figure 2. Comparison of level of EFP implementation in 2010 and 1999 samples. Difference in percent implementation between 1999 and 2010 is statistically significant (Mann Whitney Test, $\mathrm{P}<0.0001$ ) 
Table 1. Percent Completed or started, Cost and Time to Implement by Topic / Worksheet

\begin{tabular}{|c|c|c|c|c|}
\hline Worksheet / Topic* & $\begin{array}{l}1999- \\
\text { Average } \\
\text { Percent of } \\
\text { Actions } \\
\text { Completed/ } \\
\text { started }\end{array}$ & $\begin{array}{l}2010- \\
\text { Average } \\
\text { Percent of } \\
\text { Actions } \\
\text { Completed/ } \\
\text { started }\end{array}$ & $\begin{array}{l}2010 \text { - Average } \\
\text { Cost of } \\
\text { implementation } \\
(\mathrm{C} \$ 000 \mathrm{~s})\end{array}$ & $\begin{array}{l}2010 \text { - Average } \\
\text { Number of } \\
\text { Hours spent on } \\
\text { implementation }\end{array}$ \\
\hline $2-$ Water Wells & $59 \%$ & $69 \%$ & $\$ 3.00$ & 8 \\
\hline 3 - Pesticide Handling and Storage & $47 \%$ & $60 \%$ & $\$ 1.70$ & 41 \\
\hline 4 - Fertilizer Handling and Storage & $49 \%$ & $63 \%$ & $\$ 1.90$ & 11 \\
\hline 5 - Storage of Petroleum Products & $37 \%$ & $53 \%$ & $\$ 1.40$ & 6 \\
\hline 6 - Disposal of Farm Wastes & $66 \%$ & $78 \%$ & $\$ 1.20$ & 7 \\
\hline 7 - Treatment of Household Water & $59 \%$ & $68 \%$ & $\$ 1.30$ & 2 \\
\hline $\begin{array}{l}8 \text { - On-Farm Storage of Livestock } \\
\text { Manure and Other Prescribed Materials }\end{array}$ & $56 \%$ & $59 \%$ & $\$ 53.40$ & 95 \\
\hline $\begin{array}{l}9 \text { - Livestock Yards and } \\
\text { Outdoor Confinement Areas }\end{array}$ & $48 \%$ & $69 \%$ & $\$ 10.80$ & 34 \\
\hline 10 - Silage Storage & $37 \%$ & $49 \%$ & $\$ 1.40$ & 5 \\
\hline 11 - Milking Centre Washwater & $36 \%$ & $61 \%$ & $\$ 9.80$ & 18 \\
\hline $\begin{array}{l}12 \text { - Nuisances under the Farming and } \\
\text { Food Production Protection Act }\end{array}$ & $39 \%$ & $60 \%$ & $\$ 6.80$ & 6 \\
\hline 13 - Water Efficiency & $58 \%$ & $41 \%$ & $\$ 3.30$ & 11 \\
\hline 14 - Energy Efficiency & $55 \%$ & $60 \%$ & $\$ 20.20$ & 8 \\
\hline 15 - Soil Management & $67 \%$ & $78 \%$ & $\$ 21.00$ & 28 \\
\hline 16 - Nutrient Management in Growing Crops & $53 \%$ & $54 \%$ & $\$ 2.70$ & 11 \\
\hline $\begin{array}{l}17 \text { - Use and Management of Manure } \\
\text { and Other Organic Materials }\end{array}$ & $38 \%$ & $50 \%$ & $\$ 4.40$ & 11 \\
\hline 18 - Horticultural Production & $37 \%$ & $79 \%$ & $\$ 7.10$ & 41 \\
\hline 19 - Field Crop Management & $50 \%$ & $72 \%$ & $\$ 9.90$ & 48 \\
\hline 20 - Pest Management & $56 \%$ & $76 \%$ & $\$ 13.20$ & 10 \\
\hline $\begin{array}{l}21 \text { - Stream, Ditch, and } \\
\text { Floodplain Management }\end{array}$ & $68 \%$ & $68 \%$ & $\$ 9.70$ & 30 \\
\hline 22 - Wetlands and Wildlife Ponds & $58 \%$ & $63 \%$ & $\$ 3.00$ & 9 \\
\hline 23 - Woodlands and Wildlife & $58 \%$ & $48 \%$ & $\$ 3.80$ & 71 \\
\hline
\end{tabular}

* Worksheet \#1 is site and soils evaluation that provides the resource inventory for risk assessment in worksheets $2-23$

The level of implementation of actions by topic or worksheet in both 1999 and 2010 is shown in Table 1 as well as the time and funding devoted to each topic. The worksheets with the greatest portion of activities completed (between 76\% and 79\%) are Disposal of Farm Wastes, Soil Management, and Pest Management and Horticultural Production. The worksheets with the greatest portion of activities that have not been started (between $41 \%$ and 53\%) are Water Efficiency, Storage of Petroleum Products, Use and Management of Manure and Other Organic Materials, Woodlands and Wildlife and Silage Storage. Compared with 1999, save two worksheets, the percentage of activities completed and ongoing has increased.

Most socio-economic factors did not have significant effect on EFP implementation. The percentage of the action plan completed or ongoing does not appear to vary significantly by the age of the producer, farming experience, length of time since EFP preparation, farm revenue, farm size, education or off-farm income. This is an encouraging finding, that implementation was not influenced by factors that often do affect participation and action (Burton, 2014; Prokopy et al., 2008). This is tempered by the fact that participants in this survey are likely early to mid-adopters, given that about 38\% of Ontario farms had EFPs in 2011 (Statistics Canada, 2013).

Nevertheless, total cost of EFP implementation was statistically correlated with percent implementation (Figure 3 ). While the variation is large, the relationship is highly significant ( $\mathrm{F}$ test value $=14.8, \mathrm{P}<0.00001$ ). Few farms get close to $100 \%$ implementation without significant expenditure. Access to credit could be a factor limiting the level of implementation, as Canadian incentive programs are based on reimbursement after projects are 
complete.

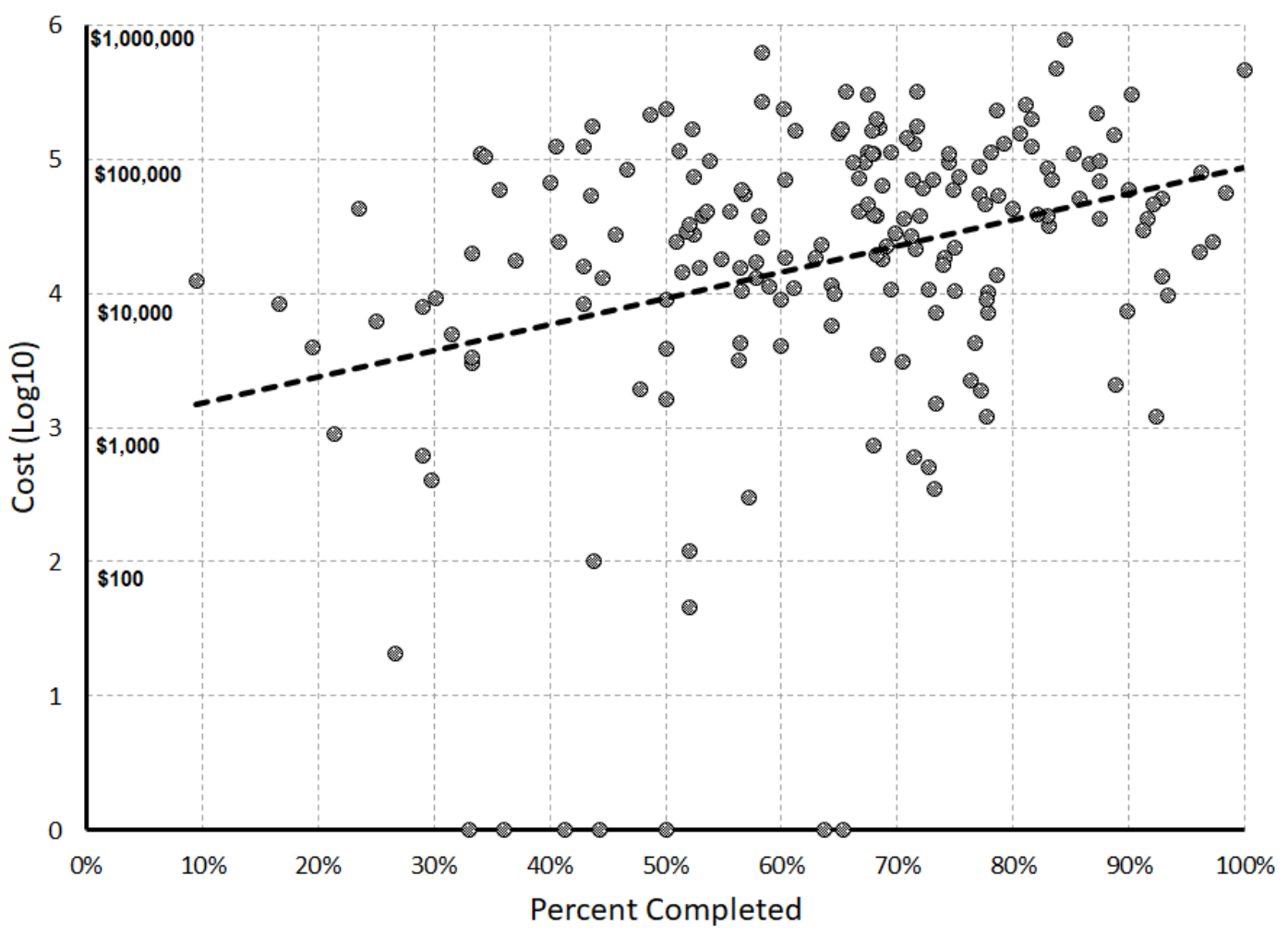

Figure 3. Percent of actions completed versus total implementation cost

Since achieving full implementation of EFPs is clearly the goal, participants were also asked what barriers prevented further implementation, the implementation of those activities identified but not yet started. The EFP action plan is meant to be implemented over time, with higher priority activities done first. When producers were asked about the status of remaining uncompleted actions, 30\% in 1999 and 32\% in 2010 said these were not immediate priorities, suggesting there were other projects they would like to complete first. Finance issues appear important for these uncompleted activities. In both 1999 and 2010, 23\% said they lacked finances to implement the project or the cost was too high (15\% in 1999 and 17\% in 2010), which may suggest they were funding other projects or do not have adequate access to credit to fund the project. Conversely, in both 2010 and 1999, producers did not identify any specific barriers to implementing $23 \%$ and $18 \%$ of activities, respectively. This may simply reflect the natural time lag between the plan and its implementation or that specific barriers exist for some actions and not for others.

\subsection{Time and Cost to Implement Action Plans}

The creation and implementation of an EFP action plan requires time and financial investments from producers, including considerable effort before any on-farm changes are completed. Participants said it took them an average of 5.2 hours outside of the workshop to complete the workbook and action plan (Table 2).

Table 2. Time and Costs of EFP Implementation in 1999 and 2010

\begin{tabular}{lll}
\hline & 1999 All Farms & 2010 All Farms \\
\hline Average hours to complete EFP workbook and Action Plan & N/A & 5.2 \\
Average Number of Hours on EFP Implementation & 53 & 163 \\
Average total cost per farm (2010 value in C $\$$ ) & $\mathrm{C} \$ 13,500$ & $\mathrm{C} \$ 69,600$ \\
Average Percent self-funded per farm & - & $77.4 \%$ \\
Average Percent cost-share funding per farm & - & $22.4 \%$ \\
\hline
\end{tabular}

Producers made significant time and financial investments in agri-environmental projects to implement their EFP action plans (Tables 2 and 3). Overall, producers implemented agri-environmental activities valued at an average of $\mathrm{C} \$ 69,600$ per farm (2010 value). Interestingly, for $42 \%$ of the activities completed, producers said there were 
no implementation costs or did not report them. Producers devoted an average of 163 hours of their time per farm to implementing activities. Time and costs were not significantly different between crop, livestock and horticultural producers (Table 3). Activities associated with four worksheets account for $72 \%$ of the total implementation cost: On-Farm Storage of Livestock Manure and Other Prescribed Materials, Soil Management, Energy Efficiency, and Pest Management (Table 1). Improved management of manure was a high-profile issue in Ontario after the Walkerton drinking water tragedy of 2000 (Lambda et al., 2009; Robinson, 2006a, b), and significant funding was available for cost sharing on nutrient management projects.

Farmers used their own finances to cover over three-quarters (77.4\%) of the cost of implementing activities (Table 2). The remaining $22 \%$ of the costs were financed through government cost-share funding. On average, the cost of activities implemented by each producer was $C \$ 69,600$, which is up $415 \%$ from $C \$ 13,500$ in 1999 (Table 2; all $2010 \mathrm{C} \$$ values).

Table 3. Time and Costs of EFP Implementation in 2010 for Field Crop, Livestock and Horticulture Farms. No significant differences between farm types in 2010 for costs and hours

\begin{tabular}{llll}
\hline & Field Crop Farms & Livestock Farms & Horticulture Farms \\
\hline $\begin{array}{l}\text { Average hours to complete EFP workbook } \\
\text { and action plan }\end{array}$ & 6.0 & 4.3 & 5.6 \\
$\begin{array}{lll}\text { Average Number of Hours on EFP Implementation } \\
\text { Average total cost per farm (2010 value in C } \$ \text { ) }\end{array}$ & 184 & & \\
Average Percent self-funded per farm & $82.6 \%$ & 131 & 248 \\
Average Percent cost-share funding per farm & $17.4 \%$ & $72.6 \%$ & $\mathrm{C} \$ 30,900$ \\
\hline
\end{tabular}

\subsection{Motivation for Participation}

The study sought to identify farmers' motivations for developing their EFP and investing in implementation activities. The most common motivations that producers cited for attending workshops were access to funding, education and assessing farm risks (Figure 4). Virtually all producers (94\%) attended an EFP workshop so they could access cost-share funding, and often had a specific agri-environmental project they wanted to implement related to a known issue on their farms. The vast majority of producers (87\%) also reported attending an EFP workshop for educational purposes-such as evaluating agricultural concerns on their farm, increasing their understanding of agri-environmental issues, and learning more about environmental regulations. The EFP workshops and workbooks are successfully helping producers identify and understand the nature of potential environmental concerns on their farms.

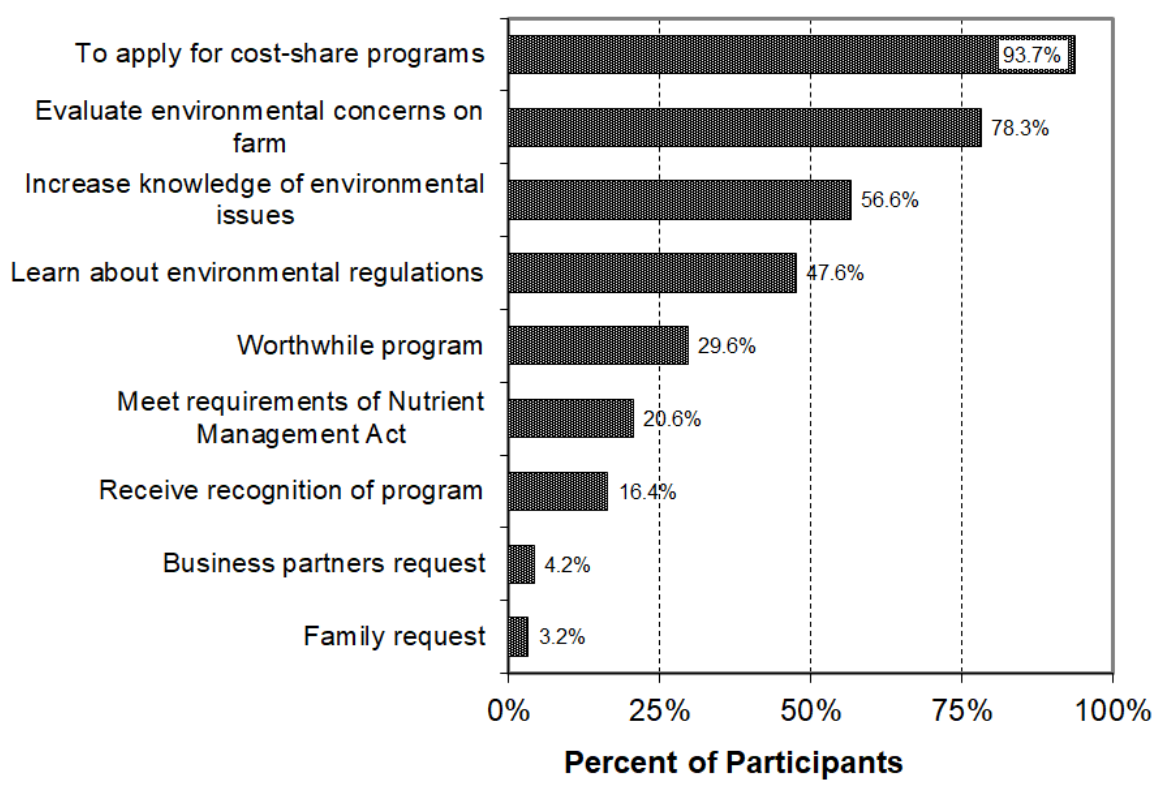

Figure 4. Motivation for participation in EFP program among the 189 participants surveyed (multiple answers possible, totals add to more than $100 \%$ ) 
Given the educational nature of the EFP workshops, one would expect that the knowledge gained may change producers' environmental priorities for their farm. While just under two-thirds $(62 \%)$ of responding producers went to the EFP workshop with a clear environmental project in mind (e.g. manure storage, no till equipment), almost half of the respondents $(45 \%)$ said, because of what they learned in the workshop, their priorities for environmental projects for their farm changed. They spoke of how the workshops increased their awareness and knowledge of agri-environmental issues and concerns, motivated them to take action, and helped them prioritize projects.

Motivation for action was statistically influenced by the farmer's main commodity $\left(\chi^{2}=26.2, \mathrm{df}=16 \mathrm{P}<0.05\right)$. Farmers of horticultural crops were somewhat more likely to be motivated by interest in education on risks than other farmers.

\subsection{Services Used and Influences for EFP Preparation and Implementation}

The research sought to analyze what services, educational resources, influences and advisors affected farmers' preparation and implementation of their EFPs. Figure 5 shows the sources of information, influence and advice reported by EFP participants to complete their EFP.

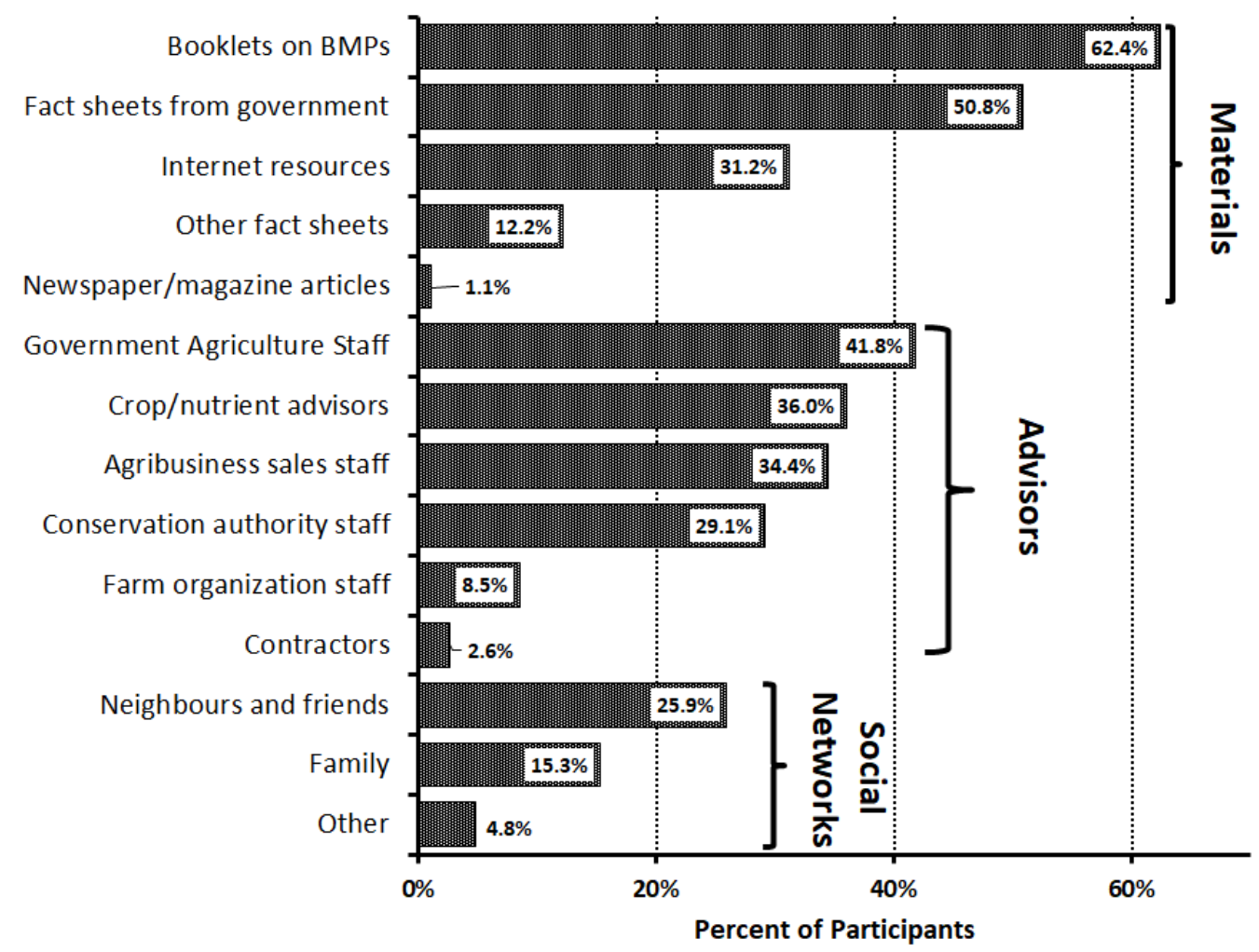

Figure 5. Reported services, information sources, influencers and advisors used to complete EFP for participants

Educational information has traditionally been made available in print form and now increasingly in a variety of digital formats on various internet platforms. In 2010, available resources were transitioning from a predominantly hard copy format to digital formats, now more widely accessed. The results reveal the gap in accessing digital formats, older farmers used fact sheets and government advisors, while younger farmers used internet sources more $\left(\chi^{2}=42.7, \mathrm{df}=28, \mathrm{P}<0.03\right)$.

The data also confirms the important role of advisors and social networks, extension staff, crop and agri-business advisors and neighbours, family, and friends (Figure 5). This is a strong theme in the literature on best management practice (BMP) adoption (e.g., Baird et al., 2016; Prokopy et al., 2008). These farmers are active EFP program participants and most would likely fall into the early to mid-adopter category (Rogers, 2010) so their reliance on government advisors is understandable. Livestock producers relied most on government and nutrient advisors, understandable in that era of compliance with new nutrient management legislation (Robinson, 2006a, b). Crop producers relied most on agri-business staff, which is typical in many jurisdictions (Prokopky et al., 2008). 


\subsubsection{Social Factors Influencing Farmers' Perception of EFP Workshop}

Social factors also affected the evaluation of the characteristics of EFP workshops. Participants with high school or less education were less satisfied with the length of workshop $\left(\chi^{2}=12.8, \mathrm{df}=6, \mathrm{P}=0.046\right)$, the range of issues discussed $\left(\chi^{2}=16.3, \mathrm{df}=6, \mathrm{P}=0.012\right)$, and the amount of one-on-one assistance $\left(\chi^{2}=18.0, \mathrm{df}=6, \mathrm{P}=0.006\right)$. Participants with higher levels of educational attainment generally tended to be more satisfied with these workshop characteristics. This is logical and consistent with the literature on extension and adoption. Participants with more years of experience in farming tended to be more satisfied with the workshops including the range of issues discussed $\left(\chi^{2}=10.5, \mathrm{df}=3, \mathrm{P}=0.015\right)$, number of worksheets covered $\left(\chi^{2}=10.7, \mathrm{df}=3\right.$, $\mathrm{P}=0.013)$, how to apply for funding $\left(\chi^{2}=9.2, \mathrm{df}=3, \mathrm{P}=0.026\right)$, and the examples provided $\left(\chi^{2}=12.0, \mathrm{df}=3\right.$, $\mathrm{P}=0.007)$.

\subsection{Possible Services to Assist in EFP Preparation}

Preparing the EFP worksheets and the action plan is a crucial step (Figure 1). Participants were asked what additional program services might help them prepare the EFP worksheets and action plan (Figure 6). About 6 in 10 said additional technical information (67\%), on-farm assistance to complete the action plan (64\%), or more one-on-one assistance in person (61\%) would or may have been helpful. About 4 in 10 said group sessions to complete the action plan (44\%), a digital version of the workbook (39\%), or more assistance over the phone or by email (38\%) would or may have been helpful.

\subsubsection{Social Factors Influencing Perception of Services to Assist EFP Preparation}

Some social factors had a modest influence on what additional program services were preferred to assist in EFP preparation. Time since participating in the EFP workshop influenced desire for group sessions $\left(\chi^{2}=24.7, \mathrm{df}=9\right.$, $\mathrm{P}=0.003)$, additional technical information $\left(\chi^{2}=19.1, \mathrm{df}=9, \mathrm{P}=0.024\right)$, more assistance by phone or email $\left(\chi^{2}=\right.$ 21.6, $\mathrm{df}=9, \mathrm{P}=0.014)$ or a digital version of the $\mathrm{EFP}$ workbook $\left(\chi^{2}=17.5, \mathrm{df}=9, \mathrm{P}=0.041\right)$. Participants who completed their EFPs a few years before (2006-09) favoured the mentioned services. Both commodity $\left(\chi^{2}=13.4\right.$, $\mathrm{df}=6, \mathrm{P}=0.037)$ and education $\left(\chi^{2}=13.3, \mathrm{df}=6, \mathrm{P}=0.038\right)$ had a small effect on desire for group sessions to complete the EFP.

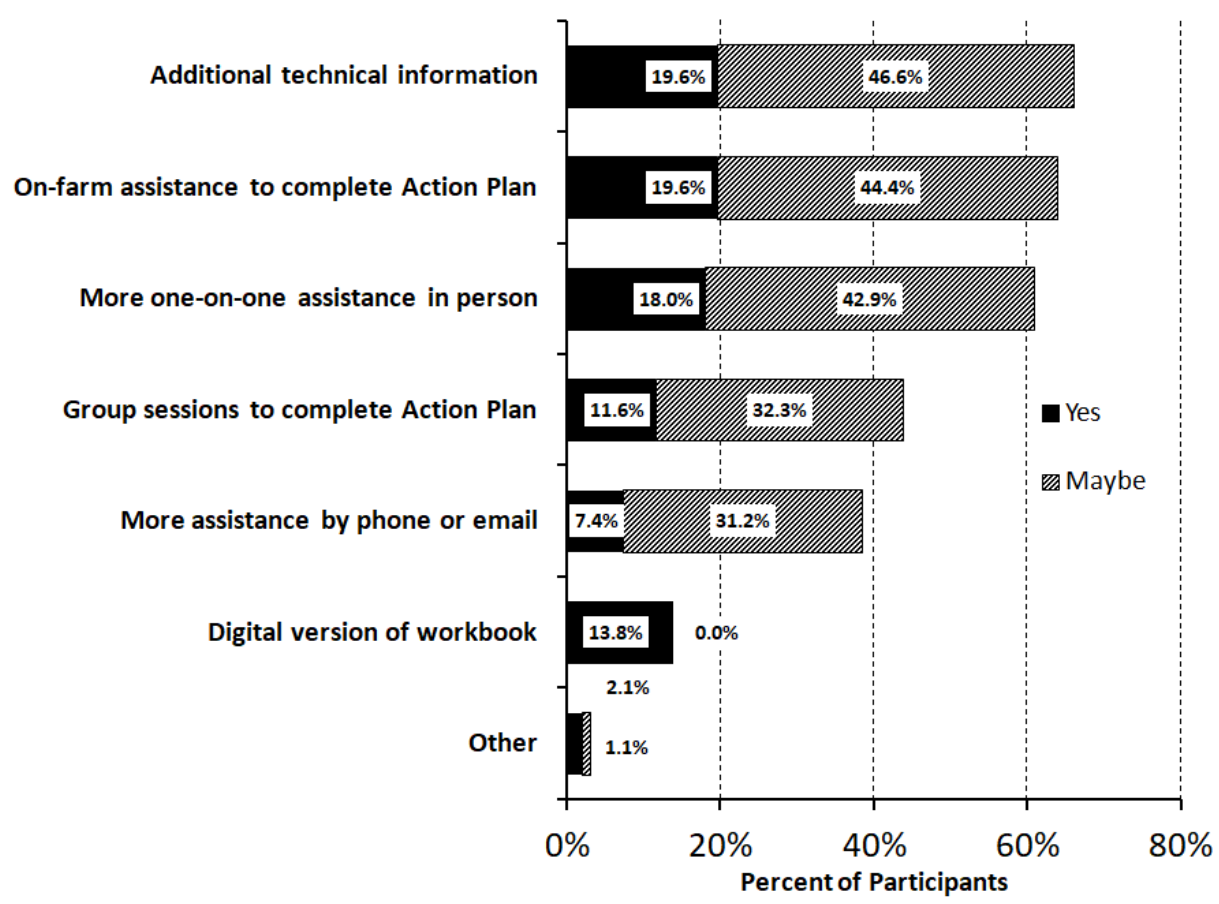

Figure 6. Preferences for potential additional services to help prepare EFP action plans

\subsection{Possible Services to Improve EFP Implementation}

Implementation of EFP action plans is the ultimate step (Figure 1), and can be complex and expensive, so farmers utilize different services to implement actions. Respondents were asked what additional services would help them implement their action plan (Figure 7). The top three services preferred all involved on-farm activities: 
tours of environmental practices used on other farms (67\%), one-to-one on-farm visits by technical specialists (52\%), and on-farm demonstrations of specific practices or technologies $(47 \%)$. These services may help meet the different needs of different types of producers, encourage producers to implement a greater portion of their action plans, and encourage other producers to participate in the EFP Program. These are also services often identified in the literature as significant in spurring action by farmers (Singh et al., 2018; Baird et al., 2016; Prokopy et al., 2008).

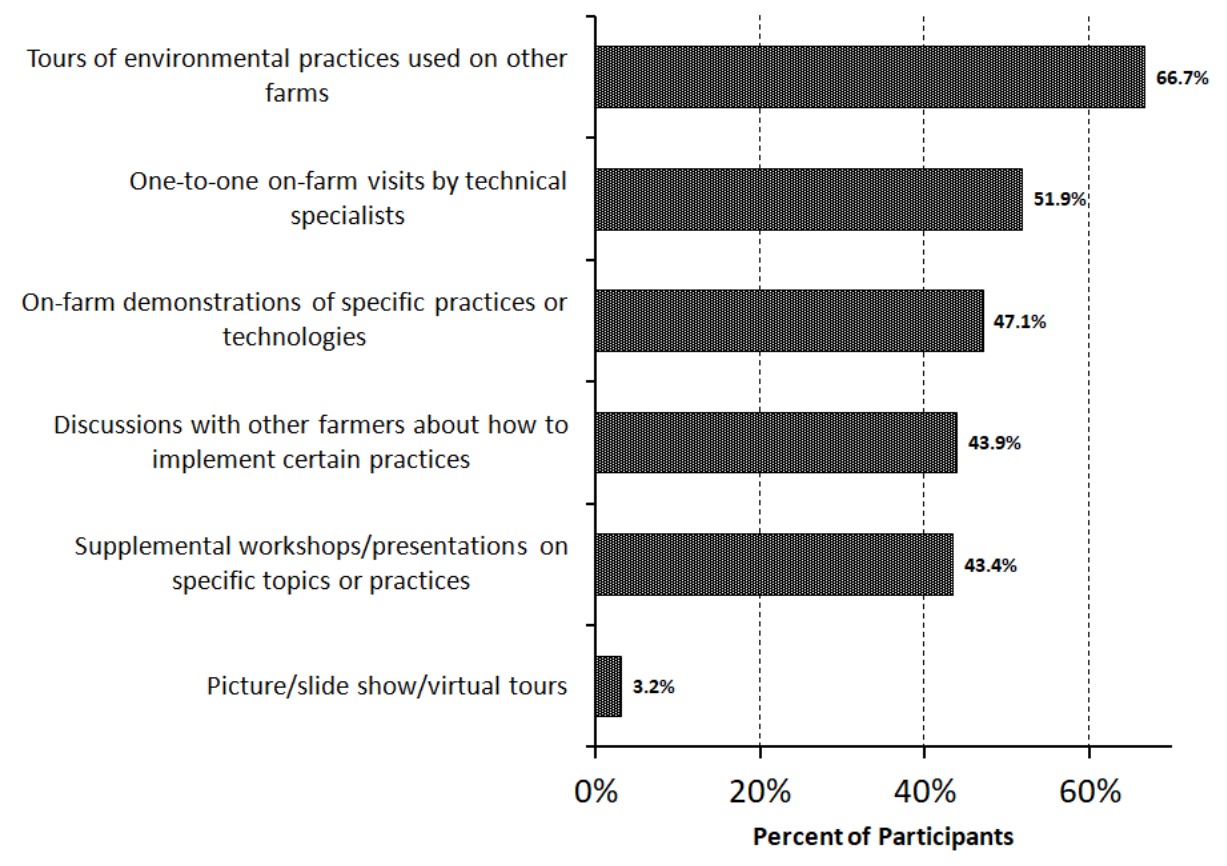

Figure 7. Preferences for potential additional services to help implement EFP action plans

\subsection{Perceived Effect of Environmental Farm Plans}

Virtually all producers (95\%) reported their EFP had at least some impact on their farming operation. Consistent with the expected outcomes of the EFP development process, producers reported that the EFP increased their awareness and understanding of agri-environmental issues and concerns, increased their implementation of actions to address agri-environmental issues, and helped them observe environmental and financial benefits. The range of impacts identified in 2010 and 1999 were similar. About half of the respondents (48\%) said that by completing an EFP, they identified some unexpected environmental benefits for their operation. Many of the stated benefits related to increased awareness and understanding or improvements to specific farm management practices.

Many producers reported that their EFP resulted in some or significant perceived improvement to various aspects of their farm operation: 74\% reported improvement to soil quality, $71 \%$ noticed improvement to water quality, $63 \%$ found improvement to family health and safety, and $48 \%$ saw improvement to fish and wildlife habitat. Of course, these are subjective perceived benefits, but can be strong motivators for action. Some producers used their EFP to meet Nutrient Management Act requirements (20\%), counter claims regarding the environmental impact of their farm (9\%), qualify for other certifications or program opportunities $(8 \%)$, or achieve a favourable loan rate or insurance premium (3\%).

\section{Discussion and Conclusion}

Canada's EFP has evolved through a long track record of building trust among farmers and grown to a national standard for action and this study confirms those important results in terms of implementation and investments to improve environmental quality. Yet participation in the EFP program was only 38\% of farms in Ontario and 35\% across Canada in 2011, now increased to $46 \%$ and 40\% respectively in 2016 (Statistics Canada, 2019, 2013). Understanding and addressing barriers to completing and implementing EFPs is important for increasing farmer participation and effectiveness. 


\subsection{Implementation of EFPs}

Evaluating the implementation of EFPs and similar risk assessment tools and their effect on the environment is an ongoing challenge. The BMP adoption literature often treats adoption or participation as a binary condition, not a quantitative state to be estimated or measured (Ulrich-Schad et al., 2017). Clearly, EFPs are planning documents and many may never be $100 \%$ implemented for a variety of reasons. Smithers and Furman (2003) had a method for measuring EFP participation based on stage of participation from workshop participation to implementation. Robinson (2006a, b) used EFP worksheets to assess the types of activities being undertaken, but not to assess level of implementation. Those approaches were suitable for a new program. As a program matures, more detailed, informative measures are needed. The Canadian federal government has done sample surveys to track EFP participation and full, partial and little implementation (Statistics Canada, 2013; AAFC, 2009). The 1999 Ontario EFP survey (Summers et al., 2008; Plummer et al., 2007) and the current survey from 2010 offer a far more detailed accounting of the actions taken and time and costs required.

The observed increase in percent implementation of EFPs from 55.0\% in 1999 to 67.5\% in 2010 is not surprising given the surge in available funding during the Agricultural Policy Framework after 2003 (Smith, 2015; Robinson, 2006a, b) and the maturing of the EFP program (Morrison and Fitzgibbon, 2014). Statistics Canada (2013) reported that in $201138 \%$ of farmers reported full implementation and 56\% reported partial implementation in Ontario in response to a qualitative survey question. That ordinal qualitative survey response and the detailed accounting in this study, while not fully comparable, generally corroborate each other. For ongoing performance measurement, repeating sample surveys like the 1999 and 2010 surveys of EFP participants, would enable tracking of EFP effectiveness while maintaining confidentiality. Broad implementation of the digital, online version of the EFP workbook and action plan could facilitate sample surveys further, while again, protecting confidentiality.

Efforts are underway to explore potential development of systems to use EFP for sustainability assessment for market purposes (Wilton and Smith, 2017). This includes the benchmarking of EFP to the Farm Sustainability Assessment standard of the Sustainable Agriculture Initiative platform (Sustainable Agriculture Initiative Platform, 2019). Assessments of the level of EFP implementation will be useful for this work as well.

\subsection{Cost of Implementation}

Financing implementation of EFPs is a complex task for the many types of farms and commodities, that vary in income, debt load, profitability, production systems and social factors. This study re-emphasizes that the range of actions needed to implement EFPs vary from simple changes that have no cost to major construction projects worth tens of thousands of dollars or more. Of course, cost of implementation is a commonly identified barrier to agri-environmental action and cost sharing assists in reducing that barrier (Carlisle, 2016). In this study, few farms approached full implementation without very significant expenditures. Cost sharing programs are clearly an important tool to increase implementation as others have also shown (Vercammen, 2019; Roesch-McNally, Basche, Arbuckle, \& Tyndall, 2018). However, many agri-environmental cost sharing program models prevalent in North America generally require private debt financing with reimbursement post-project, so access to credit may also be a barrier to some producers (Liu, Bruins, \& Heberling, 2018).

\subsection{Motivation, Services Used and the Influence of Social Factors}

The early, mid, late and non-adopter approach to categorizing farmers' behaviours (Rogers, 2010) is useful in thinking about differences in motivation, barriers and services to support changes in practices. Ways of thinking, concerns and priorities vary along the adoption spectrum (Carlisle, 2016). But knowledge about the motivation and decision-making behaviours of non-adopters and potential adopters is poorly known (Carlisle, 2016; Schaible et al., 2015). Given the preoccupation of agri-environmental policy makers with increasing adoption, it is surprising that research on the motivation and decision making of potential adopter and non-adopter farmers is not a higher priority (Carlisle, 2016).

The tools of education, awareness building, risk assessment and financial incentives are cornerstones of agri-environmental policy in many jurisdictions, often coupled with some regulatory or cross compliance measures (OECD, 2010, Reimer et al., 2012, Singh et al., 2018). Evidence supports the need for combinations of policy tools or instruments for greater effectiveness (OECD, 2010) and this study emphasizes the importance of combining education, risk assessment and incentives to spur investment in environmental improvements.

This study demonstrated that use of, and receptiveness to different extension services was influenced by age, education, commodity, farming experience and other factors. These services like demonstrations, advice, and outreach continue to be proven to be effective with a range of segments of the farm population (Dessart et al. 
2019; Singh et al., 2018; Reimer et al., 2012; Rodriguez et al., 2008). New digital platforms offer new opportunities for outreach (Chowdhury and Hambly Odame, 2013). This study confirms the need to offer a range of services to appeal to the diversity of producers and their varying learning styles.

The survey found that producers used the services available through the EFP workshops and technical advice from government agriculture staff and other organizations or publications. About two-thirds of the producers surveyed said additional services and assistance would or might help them implement their action plans. Agri-business advisors are also identified as a significant source of knowledge, particularly for cash crop producers. More one-on-one advice was identified as a desired service to enhance EFP implementation. The influence of advisors on farmers' decision making can be fundamental (Baird et al., 2015). So shortcomings in knowledge of advisors about agri-environmental practices is a growing concern (Ingram \& Morris, 2007).

Social networks and social norms have been shown to be important influences on farmers' learning and decision-making (Dessart et al. 2019; Simpson, 2011; Pannell et al., 2006). In this study, friends, neighbours and family are identified as an important, although not dominant, source of information on how to implement EFP action plans. Enhancing peer-to-peer social interaction among farmers can take many forms, such as establishing forums for peer discussion, mentorship, or environmental clubs.

Farmers' social characteristics affect their motivation, influences and use of services for EFP preparation and implementation. Expanding the variety of methods used to reach and provide information to farmers will help address the diversity within the farm community. Undoubtedly, the motivations and needs of the $54 \%$ of farmers in Ontario (2016) that do not have an EFP will be different and research should be done to explore those needs to improve program effectiveness.

\subsection{Conclusion}

Canada's EFP has proven an enduring program, started by farmers themselves and supported by governments. Assessing the level of implementation is an important step in the evolution of the EFP, as is evaluating the services that support EFP preparation and implementation. Social factors can influence participation and use of different services. This evaluation research revealed high levels of implementation of EFP action plans, potential ways to monitor implementation and an understanding on how the actions were financed and carried out. The influence of social factors on use of, and preference for, information sources and services offers insights on how to accomodate the diversity of farmers in Ontario and Canada. These insights can help guide efforts to reach beyond the 46\% of farms in Ontario and 40\% across Canada that reported having an EFP in 2016 (Statistics Canada, 2019). This long-standing, collaborative partnership of governments with farm organizations continues to evolve, gain support and spread across the country. Recent efforts to use the EFP as part of a system to assess sustainability for market requirements can only benefit from this research documenting implementation.

\section{Acknowledgements}

Thanks to all the farmers who developed and implemented their Environmental Farm Plans and made investments to reduce environmental risks since 1994. Thanks to the farmers who participated in this survey and the staff involved from Ontario Soil and Crop Improvement Association, Ontario Federation of Agriculture, Agriculture and Agri-food Canada, and Ontario Ministry of Agriculture, Food and Rural Affairs. Finally, thanks to Erin Nelson, Aaron Smith and anonymous reviewers who reviewed the manuscript.

\section{References}

Agriculture and Agri-Food Canada. (2009). Environmental Farm Planning in Canada: A 2006 Overview. Farm Environmental Management in Canada, Technical Series Report. Ottawa, Ontario: Agriculture and Agri-Food Canada, 2009. Retrieved from

http://publications.gc.ca/collections/collection_2011/agr/A125-15-2011-eng.pdf

Agriculture and Agri-Food Canada and Ministry of Agriculture Food and Rural Affairs. (2018). New five-year partnership will help grow province's agri-food sector. Retrieved from https://www.canada.ca/en/agriculture-agri-food/news/2018/02/ontario_and_canadamarkagriculturedaywithl andmarkagreement.html

Ansell, D., Gibson, F., \& Salt, D. (2016). Learning from agri-environment schemes in Australia: investing in biodiversity and other ecosystem services on farms. Australian National University Press, Acton ACT, Australia. pp. 310.

Baird, J., Jollineau, M., Plummer, R., \& Valenti, J. (2016). Exploring agricultural advice networks, beneficial management practices and water quality on the landscape: A geospatial social-ecological systems analysis. 
Land Use Policy, 51, 236-243. https://doi.org/10.1016/j.landusepol.2015.11.017

Barnes, A., Willock, J., Toma, L., \& Hall, C. (2011). Utilising a farmer typology to understand farmer behaviour towards water quality management: Nitrate Vulnerable Zones in Scotland. Journal of Environmental Planning and Management, 54, 477-494. https://doi.org/10.1080/09640568.2010.515880

Baumgart-Getz, A., Prokopy, L., \& Floress, K. (2012). Why farmers adopt best management practice in the United States: A meta-analysis of the adoption literature. Journal of Environmental Management, 96, 17-25. https://doi.org/10.1016/j.jenvman.2011.10.006

Blackstock, K., Ingram, J., Burton, R., Brown, K., \& Slee, B. (2010). Understanding and influencing behaviour change by farmers to improve water quality. Science of the Total Environment, 408, 5631-5638. https://doi.org/10.1016/j.scitotenv.2009.04.029

Boxall, P. (2018). Evaluation of agri-environmental programs: can we determine if we grew forward in an environmentally friendly way? Canadian Journal of Agricultural Economics, 66, 171-186. https://doi.org/10.1111/cjag.12170

Burton, R. J. F. (2014). The influence of farmer demographic characteristics on environmental behaviour: A review. Journal of Environmental Management, 135, 19-26. https://doi.org/10.1016/j.jenvman.2013.12.005

Chowdhury, A., \& Hambly, O. H. (2013). Social media for enhancing innovation in agri-food and rural development: current dynamics in Ontario, Canada. Journal of Rural and Community Development, 8, 97-119.

Carlisle, L. (2016). Factors influencing farmer adoption of soil health practices in the United States: A narrative review. Agroecology and Sustainable Food Systems, 40, 583-613. https://doi.org/10.1080/21683565.2016.1156596

Clearwater, R., Martin, T., \& Hoppe, T., (Eds.) (2016). Environmental sustainability of Canadian agriculture: Agri-environmental indicator report series - Report \#4. Ottawa, ON: Agriculture and Agri-Food Canada.

de Olde, E., Oudshoorn, F., Sørensen, C., Bokkers, E., \& de Boer, I. (2016). Assessing sustainability at farm-level: Lessons learned from a comparison of tools in practice. Ecological Indicators, 66, 391-404. https://doi.org/10.1016/j.ecolind.2016.01.047.

Dessart, F. J., Barreiro-Hurlé, J., \& van Bavel, R. (2019). Behavioural factors affecting the adoption of sustainable farming practices: a policy oriented review. European Review of Agricultural Economics, 46, 417-471. https://doi.org/10.1093/erae/jbz019

Faifua, D. (2014). The key informant technique in qualitative research. SAGE Research Methods Cases. https://doi.org/10.4135/978144627305014540254

Franz, N., Piercy, F., Donaldson, J., Richard, R., \& Westbrook, J. (2010). How farmers learn: implications for agricultural educators. Journal of Rural Social Sciences, 25, 37-59.

Ingram, J., \& Morris, C. (2007). The knowledge challenge within the transition toward sustainable soil management: An analysis of agricultural advisors in England. Land Use Policy, 24, 100-117. https://doi.org/10.1016/j.landusepol.2005.07.002

Inwood, S. E., López-Ridaura, S., Kline, K., Gérard, B., Gardeazabal, M. A., Govaerts, B., \& Dale, V. (2018). Assessing sustainability in agricultural landscapes: a review of approaches. Environmental Reviews, 26, 299-315. https://doi.org/10.1139/er-2017-0058

Lamba, P., Filson, G., \& Adekunle, B. (2009). Factors affecting the adoption of best management practices in southern Ontario. Environmentalist, 29, 64-77. https://doi.org/10.1007/s10669-008-9183-3

Leppälä, J., Rautiainen, R., \& Kauranen, I. (2015). Analysis of risk management tools applicable in managing farm risks: A literature review. International Journal of Agricultural Management, 4, 110-122. https://doi.org/10.5836/ijam/2015-03-110

Liu, T., Bruins, R. J. F., \& Heberling, M. T. (2018). Factors Influencing Farmers' Adoption of Best Management Practices: A Review and Synthesis. Sustainability, 10, 432. https://doi.org/10.3390/su10020432

Manderson, A. K., Mackay, A. D., \& Palmer, A. P. (2007). Environmental whole farm management plans: Their character, diversity, and use as agri-environmental indicators in New Zealand. Journal of Environmental Management, 82, 319-331. https://doi.org/10.1016/j.jenvman.2005.05.020

Morrison, K., \& FitzGibbon, J. (2014). Adaptive governance of dynamic social-ecological systems: the case of 
the Ontario Environmental Farm Plan (1992-2011). Agroecology and Sustainable Food Systems, 38, 378-409. http://dx.doi.org/10.1080/21683565.2013.870627

Organisation for Economic Co-operation and Development. (2013). OECD Compendium of Agri-environmental Indicators, OECD Publishing. http://dx.doi.org/10.1787/9789264181151-en

Organisation for Economic Co-operation and Development. (2010). Guidelines for Cost-effective Agri-environmental Policy Measures. OECD Publishing.

Ontario Farm Environment Coalition, Agriculture and Agri-Food Canada \& Ontario Ministry of Agriculture Food and Rural Affairs. (2013). Canada-Ontario Environmental Farm Plan. Fourth edition workbook, Guelph, ON, Canada. pp. 303.

Ontario Farm Environment Coalition. (1992). Our farm environmental agenda. Toronto.

Orris, J. B. (2015). MegaStat User's Guide, Butler University, Indianapolis, Indiana, U.S.

Pannell, D. J., Marshall, G. R., Barr, N., Curtis, A., Vanclay, F., \& Wilkinson, R. (2006). Understanding and promoting adoption of conservation practices by rural landholders, Australian Journal of Experimental Agriculture, 46, 1407-1424. https://doi.org/10.1071/EA05037

Plummer, R., Speirs, A., Summers, R., \& FitzGibbon, J. (2007). The contributors of stewardship to managing agro-ecosystem environments. Journal of Sustainable Agriculture, 31, 55-84.

https://doi.org/10.1300/J064v31n03_06

Prairie Research Associates. (2011). Environmental Farm Plans: measuring performance, improving effectiveness, and increasing participation. Unpublished report. Retrieved from

https://www.ontariosoilcrop.org/wp-content/uploads/2015/08/Final-Report-EFPs-Measuring-Performance-I mproving-Effectiveness-and-Increasing-Participation.pdf

Propoky, L.S., Floress, K., Klotthor-Weinkauf, D., \& Baumgart-Getz, A. (2008). Determinants of agricultural best management practice adoption: Evidence from the literature. Journal of Soil and Water Conservation, 63, 300-311. https://doi.org/10.2489/jswc.63.5.300

Reimer, A., Thompson, A., Prokopy, L., Arbuckle, J., Genskow, K., Jackson-Smith, D., ... Nowak, P. (2014). People, place, behavior, and context: A research agenda for expanding our understanding of what motivates farmers' conservation behaviors. Journal of Soil and Water Conservation, 69, 57A-61A. https://doi.org/10.2489/jswc.69.2.57A

Reimer, A., Klotthor, W. D., \& Prokopy, L. (2012). The influence of perceptions of practice characteristics: An examination of agricultural best management practice adoption in two Indiana watersheds. Journal of Rural Studies, 28, 118-128. https://doi.org/10.1016/j.jrurstud.2011.09.005.

Robinson, G. M. (2006a). Ontario's Environmental Farm Plan: Evaluation and research agenda. Geoforum, 37, 859-873. https://doi.org/10.1016/j.geoforum.2005.05.002

Robinson, G. M. (2006b). Canada's environmental farm plans: transatlantic perspectives on agri-environmental schemes. The Geographical Journal, 172, 206-218. https://doi.org/10.1111/j.1475-4959.2006.00207.x

Roesch-McNally, G., Basche, A., Arbuckle, J., \& Tyndall, J. (2018). The trouble with cover crops: Farmers' experiences with overcoming barriers to adoption. Renewable Agriculture and Food Systems, 33, $322-333$. https://doi.org/10.1017/S1742170517000096

Rodriguez, J. M., Molnar, J. J., Fazio, R. A., Sydnor, E., \& Lowe, M. J. (2008). Barriers to adoption of sustainable agriculture practices: Change agent perspectives. Renewable Agriculture and Food Systems, 24, 60-71. https://doi.org/10.1017/S1742170508002421

Rogers, E. M. (2010). Diffusion of innovations, $5^{\text {th }}$ edition. The Free Press, New York.

Roussy, C., Ridier, A., \& Chaib, K. (2017). Farmers' innovation adoption behaviour: role of perceptions and preferences. Int. J. Agricultural Resources, Governance and Ecology, 13, 138-161.

Sattler, C., \& Nagel, U. J. (2010). Factors affecting farmers' acceptance of conservation measures - A case study from north-eastern Germany. Land Use Policy, 27, 70-77. https://doi.org/10.1016/j.landusepol.2008.02.002

Schaible, G. D., Mishra, A. K., Lambert, D. M., \& Panterov, G. (2015). Factors influencing environmental stewardship in U.S. agriculture: Conservation program participants vs. non-participants. Land Use Policy, 46, 125-141. https://doi.org/10.1016/j.landusepol.2015.01.018

Simpson, H. (2014). The agricultural community and its contribution to collaborative environmental 
problem-solving. Ph.D., University of Waterloo, Waterloo, Ontario, Canada.

Singh, A., MacGowan, B., O'Donnell, M., Overstreet, B., Ulrich-Schad, J., Dunn, M., Klotz, H., \& Prokopy, L. (2018). The influence of demonstration sites and field days on adoption of conservation practices. Journal of Soil and Water Conservation, 73, 276-283. http://dx.doi.org/10.2489/jswc.73.3.276

Smith, P. G. R. (2015). Long-term temporal trends in agri-environment and agricultural land use in Ontario, Canada: transformation, transition and significance. Journal of Geography and Geology, 7, 32-55. http://dx.doi.org/10.5539/jgg.v7n2p32

Smithers, J., \& Furman. M. (2003). Environmental farm planning in Ontario: exploring participation and the endurance of change. Land Use Policy, 20, 343-356. https://doi.org/10.1016/S0264-8377(03)00055-3

Statistics Canada (2019). Farm Management Survey 2017. Statistics Canada, Catalogue no. 11-001-X, Ottawa, Canada.

Statistics Canada (2013). Farm Environmental Management Survey 2011. Statistics Canada, Catalogue no. 21-023-X, Ottawa, Canada.

Summers, R., Plummer, R., \& FitzGibbon, J. (2008). Accounting precautionary measures in agriculture through pathway analysis: the case of the Environmental Farm Plan. International Journal of Agricultural Resources, Governance and Ecology, 7, 437-449. https://doi.org/10.1504/IJARGE.2008.022746

Sustainable Agriculture Initiative Platform. (2019). SAI Platform Farm Sustainability Assessment (FSA) Implementation Framework. Version 2a released March 2019. Retrieved from

http://www.fsatool.com/fileadmin/user_upload/SAI_Platform_FSA_Implementation_Framework_version_2 a_released_March_2019_.pdf

Ulrich-Schad, J. D., García de Jalón, S., Babin, N., Pape, A., \& Prokopy, L. S. (2017). Measuring and understanding agricultural producers' adoption of nutrient best management practices. Journal of Soil and Water Conservation, 72, 506-518. https://doi.org/10.2489/jswc.72.5.506

Vercammen, J. (2019). A dynamic analysis of cost-share agri-environmental programs. Canadian Journal of Agricultural Economics, 67, 15-30. https://doi.org/10.1111/cjag.12193

Wauters, E., \& Mathijs, E. (2014). The adoption of farm level soil conservation practices in developed countries: a meta-analytic review. International Journal of Agricultural Resources, Governance and Ecology, 10, 78-102.

Weersink, A. (2018). The Growing Heterogeneity in the Farm Sector and Its Implications. Canadian Journal of Agricultural Economics, 66, 27-41. https://doi.org/10.1111/cjag.12163

Wilton, B., \& Smith, D. (2017). The Sustainable Farm and Food Initiative, final report. Canadian Agri-Food Sustainability Initiative. Retrieved from https://www.wiltongroup.ca/s/SFFI-Final-Report-January-3-2018.pdf

Yiridoe, E. K. (2000). Risk of public disclosure in environmental farm plan programs: characteristics and mitigating legal and policy strategies. Journal of Agricultural and Environmental Ethics, 13, 101-120.

Yiridoe, E. K., Atari, D., Gordon, R., \& Smale, S. (2010). Factors influencing participation in the Nova Scotia Environmental Farm Plan Program. Land Use Policy, 27, 1097-1106.

https://doi.org/10.1016/j.landusepol.2010.02.006

\section{Copyrights}

Copyright for this article is retained by the author(s), with first publication rights granted to the journal.

This is an open-access article distributed under the terms and conditions of the Creative Commons Attribution license (http://creativecommons.org/licenses/by/3.0/). 